\title{
To What Extent Do Regional Effects Influence Firms' Capital Structure? The Case of Southern Italian SMEs'
}

\author{
Olivier Butzbach and Domenico Sarno * (D) \\ Department of Political Science, University of Campania “L. Vanvitelli”, 81100 Caserta, Italy; \\ olivierkarl.butzbach@unicampania.it \\ * Correspondence: domenico.sarno@unicampania.it
}

Received: 20 October 2018; Accepted: 24 December 2018; Published: 4 January 2019

\begin{abstract}
There is tremendous interest, in the economic literature, for the determinants of firms' capital structure decisions. A rich body of empirical works now exists that purports to identify firmand country-level factors affecting firms' financing patterns. In addition, more recently, a new stream of studies has emerged that investigates cross-regional variation in small firms' capital structure. While small firms' leverage does seem to vary across regions, at least in countries where significant regional differences in economic and financial development and in the quality of institutions exist, not much yet is known about variation in debt maturity, in debt in relation to equity, and between different types of small firms. The present paper aims to fill this gap through an empirical analysis of cross-regional variation in the capital structure of a sample of about 30,000 Italian small firms over a 13-year period, including the aftermath of the credit crunch that followed the 2007-2008 global financial crisis. The findings confirm the view that small firms in underdeveloped regions are more financially constrained, but also amend some of the results shown in the literature, in particular by showing how small firms in Italy's Southern regions have higher levels of equity and fixed assets than small firms in other regions.
\end{abstract}

Keywords: capital structure; leverage; SMEs; cross-regional variation

JEL Classification: G32; G30; L60

\section{Introduction}

The determinants of firms' capital structure is the object of a large component of economic literature, both empirical and theoretical. Theory-wise, various arguments have been put forward concerning a firm's decision to use more debt, equity, internal funding sources, or alternative funding sources. The "pecking order" theory, first formulated by Myers (1984), is well known-but alternative theories exist, such as the "trade-off" hypothesis (See Fama and French 2002) or the financial life cycle approach (Berger and Udell 1998). Each theory generates its own set of hypotheses regarding (i) the potential preferences of firms in terms of the source of funding they wish to use to finance their investment; and (ii) the factors constraining such preferences. While hypotheses concerning preferences vary, there is a broad consensus in the literature around the likely firm-level determinants of firms' capital structure choice, i.e., firms' size, profitability, asset structure, age, and growth.

The empirical literature has largely confirmed the second set of hypotheses, e.g., those regarding the determinants of firms' capital structure choices. A firm's size is seen, in particular, as a very significant factor determining, for instance, a firm's ability to access external finance—bank debt or marketable securities. This has to do, mainly, with the greater information asymmetries presented 
by small and medium-sized firms (SMEs). Also, the literature widely confirms the hypothesis that profitable firms exhibit lower leverage; or that the greater a firm's fixed assets, the greater its long-term debts (Rajan and Zingales 1995; Wald 1999; Booth et al. 2001). Regarding the first set of hypotheses, the jury is still out: Several studies find evidence in favour of the pecking order theory (REF); others do not (see, for instance, Fama and French 2002); others yet find evidence compatible with both the pecking order theory and alternative theories (La Rocca et al. 2011).

While early empirical work was mostly based on one-country analyses, a rich stream of studies has emerged since the late 1990s to investigate cross-country variation in capital structure decisions. Indeed, such cross-country differences have now been amply documented (for instance, in works, such as Booth et al. 2001; Beck et al. 2008; Fan et al. 2012; Mateev et al. 2013). These studies have made an important contribution to the literature on capital structure decisions of large and small firms by highlighting the significance of country-effects, on top of firm and industry-effects. These country effects have been generally identified as either related to the structure and development of a country's financial system (Levine 1997, 2004) or to the quality and development of a country's institutions, especially legal institutions (Beck et al. 2003, 2005), or to both (La Porta et al. 1997, 1998). An ongoing debate in the literature regards the relative importance of country- and firm-effects (and industry effects) in determining firms' capital structure (Daskalakis and Psillaki 2008; De Jong et al. 2008; Fan et al. 2012).

However, firms' capital structure choices may also vary within countries. Indeed, many countries are characterized by significant cross-regional variation in terms of economic growth and legal and financial characteristics - the latter being often correlated with the former (see Guiso et al. 2004). In addition, small firms are likely to be more dependent upon local sources of funding, as they have a lower capacity than large firms to tap into national financial markets; small firms' access to finance is made harder by the significant information asymmetries that may characterize their relationships with potential investors. These characteristics make studies of cross-regional variation in small firms' capital structure particularly relevant to the broader academic discussion about capital structure decisions, explaining the emergence of a stream of empirical studies focusing on cross-regional variation in firms' capital structure (see La Rocca et al. 2010; Palacín-Sánchez et al. 2013; Serrasqueiro and Caetano 2015; Palacín-Sánchez and Pietro 2016; Matias and Serrasqueiro 2017).

This paper aims to contribute to this emerging literature on cross-regional-variation in the capital structure of small firms in three ways: First, by using a very large sample of SMEs during a relatively long period of time (longer than the typical time-frame used in the capital structure literature). In particular, the period under study encompasses the years following the 2007-2008 global financial crisis, which helps us measure the impact of the credit crunch on Italian SMEs' capital structure. Secondly, this paper contributes to the literature by highlighting variation in equity as well as debt; and by analyzing differences in debt maturity as well as total leverage (not systematically done in the literature). Third, our empirical strategy allows us to distinguish between different types of SMEs, given the heterogeneity of this group of firms, both in terms of characteristics and financial needs.

The Italian context is especially interesting for assessing cross-regional variation in the capital structure of small firms. First, SMEs are extremely numerous in Italy-as of 2015, Italy had 4,687,891 firms, of which only 3153 had more than 250 employees. Italian SMEs are present in all economic activities. Secondly, Italy has a historical record of significant and persistent cross-regional gaps in output growth, employment, and productivity: In 2017, GDP per capita was 18,200 Euro in Southern regions, $44.2 \%$ below that of Northern regions. This socio-economic development gap translates in the peculiar industrial structure of Southern Italy, characterized by more traditional activities, a lower average size of firms, and younger firms due to the higher turnover of firms' population. These characteristics have persisted until today.

Third, Italy has a long experience in policies (called "intervento straordinario") adopted in the 1950s and 1960s to reduce this regional gap in socio-economic development through, in particular, a dedicated funding agency - policies that have had, historically, an impact on Sothern firms' financial constraints 
and strategy. However, these policies and the dedicated agency were set aside in the early 1990s. ${ }^{1}$ At the same time, the Italian banking industry started to undergo a deep re-organization through bank privatization, banking markets de-segmentation and liberalization, and bank restructuring on a national scale. In this process, the large Southern banks, which had, in the past, played an important role in promoting and sustaining local growth, disappeared.

Finally, another set of macroeconomic factors that may have affected the capital structure of small firms in Southern Italy (especially in the latter years covered in our sample) relate to the 2007-2008 financial crisis and its consequences. In the aftermath of a credit shock, firms' financial constraints increase: Firms need to find new sources of funding for their financial needs. While large firms can easily find alternative funding sources, smaller firms have a harder time doing so, because of their opacity and riskiness; thus, they face decreasing leverage. It is likely to believe, furthermore, that these deleveraging effects are likely to be greater in less-developed areas (Beattie et al. 2006).

The analysis presented here uses data on a large panel of Italian SMEs observed over a 13-year period (from 2001 to 2013), for a total of 427,468 observations (an average of 32,882 small firms observed per year) for Italy as a whole; of which 53,971 observations (an average of 4151 small firm-observations per year) for Southern Italy only. The study compares SMEs' capital structure across Italian administrative regions, clustered in two macro-areas widely used in the literature: The less developed Mezzogiorno, composed of the eight Southern Italian regions (Abruzzo, Molise, Campania, Puglia, Basilicata, and Calabria), in addition to the two islands (Sicily and Sardinia); and the "Center-North" macro-area, composed of the other 12 administrative regions of the central and northern areas of the country. ${ }^{2}$

Our analysis confirms the existence of significant regional effects in the determinants of small firms' capital structure, in line with similar studies (Palacín-Sánchez et al. 2013; Serrasqueiro and Caetano 2015; Palacín-Sánchez and Pietro 2016; Matias and Serrasqueiro 2017). However, several findings contrast with the accepted views concerning the capital structure of small firms-especially in underdeveloped regions. First, small firms in Southern Italy tend to be over-capitalized, rather than suffering from equity shortage, as predicted by the literature (see, for instance, Carter and Auken 2006). Secondly, small firms in Southern Italy show high levels of indebtedness-and lower leverage elasticity-than in other Italian regions. Again, this runs counter to the argument that smaller firms in lagging regions may have more trouble accessing bank credit. Finally, while most firm-level determinants affect capital structure along the lines predicted in the literature, there is a negative relationship between leverage and the tangibility of assets in Southern Italian SMEs.

The rest of the paper is organized as follows. The next section reviews the existing literature on capital structure determinants in small firms. Sections 3 and 4 present the data and methodology used here. Section 5 shows descriptive statistics revealing some of the distinctive features of the financial structure of SMEs in southern Italy. Section 6 presents and discusses the findings of the empirical analysis. Section 7 concludes.

\section{Determinants of SMEs' Capital Structure: From Firm- to Country- and Region-Effects}

\subsection{Firm-Level Determinants of Capital Structure Decisions}

As argued above, the question of firms' capital structure decisions has aroused tremendous interest in the economic literature in the past. The theoretical foundations of such literature rest on the seminal work by Modigliani and Miller, and on the removal of some of the conditions

1 The law supporting the so-called "extraordinary intervention" for promoting growth in Southern regions was repealed in 1992; in the same year, the government ended the operations of Agensud (ex Cassa per il Mezzogiorno), the public agency established in 1950 and devoted to funding infrastructure in the Mezzogiorno areas.

2 The existence of a long-term North-South economic divide in Italy is well known and has led to a rich literature on the subject. The intensive interventions designed since the fifties to promote the growth of Mezzogiorno have substantially failed to achieve the convergence of the Southern area with the other regions of the Country. 
imposed by their "irrelevance theorem". In explaining firms' preference for equity, debt, or retained earnings as main sources of funding, economists alternatively stress the causal role of agency costs (Jensen and Meckling 1976; Myers 1977; Harris and Raviv 1990), information asymmetries and signalling (Ross 1977; Myers and Majluf 1984; Myers 1984), or taxation (Miller 1977; De Angelo and Masulis 1980). Particularly popular approaches to understand corporate capital structure decisions are the pecking order theory, the trade-off theory, and the financial life cycle theory. In a nutshell, the pecking order theory assumes that firms' capital structure preferences depend on financing costs; and that the latter are related to information asymmetries, so that equity financing is costlier than debt, which is costlier than internal funding; hence, corporate managers prefer internal financing over debt and debt over equity (Myers and Majluf 1984). According to the trade-off perspective, by contrast, financing decisions are based on cost-benefits' assessment balancing, in particular, the dead-weight costs of bankruptcy and the tax saving benefits of debt (Kraus and Litzenberger 1973). Finally, under the financial life cycle perspective, firms' capital structure preferences varies with their life cycle: The latter determines "the nature of [a firm's] financial needs, the availability of financial resources, and the related cost of capital" (Berger and Udell 1998, p. 108). Theoretically, the analytical strength of these various approaches is considered equally relevant for the financial strategies of the firm, ${ }^{3}$ but none of them provides an exhaustive and definitive means of explaining the actual financial (or capital structure) choices of firms.

This is especially true in the case of SMEs, where information asymmetries are believed to be higher than in large firms. In particular, small firms are deemed more "informationally opaque" than large firms (Berger and Udell 1998). From a "financial life cycle" perspective (Berger and Udell 1998; La Rocca et al. 2011), this informational opaqueness raises the cost of debt for young (and small) firms, reversing the preferences hypothesized under the pecking order theory (Berger and Udell 1998); in addition, young firms have low or no reputation, and lack tangible assets, which contributes to raising the cost of debt (La Rocca et al. 2011).

The various hypotheses formulated within the theoretical approaches briefly sketched above have been the object of a rich stream of empirical tests, which were primarily concerned with identifying the main determinants of capital structure decisions at the firm level; as mentioned in the introduction above, there is a wide consensus in the literature that such firm-level determinants are size, age, growth, profitability, and its volatility and, finally, the tangibility of assets (for examples of such consensus, see Booth et al. 2001; Hall et al. 2004; Fan et al. 2012; Matias and Serrasqueiro 2017). The nature and effects of such firm-level determinants are briefly examined below.

The effects of firm size on capital structure are potentially numerous, but they are all consistent with the idea that when the size of a firm increases, the share of debt (leverage) also increases, given that the smaller the firm, the greater the information asymmetries; and that greater information asymmetries raise the cost of debt. In addition, the impact of liquidity constraints on firm growth are likely to increase with firm size (Donati 2016). Finally, the range of funding sources available to firms is positively correlated with firm size-which increases small firms' dependence on a narrow range of sources (Lawless et al. 2015). Most empirical studies find a positive relationship between firm size and leverage, while the relationship between size and short-term debt has sometimes been found to be negative (Chittenden et al. 1996; Michaelas et al. 1999; Noulas and Genimakis 2011; Dang et al. 2018). ${ }^{4}$

Similarly, information asymmetry theory predicts a positive relationship between a firm's leverage and its age. Within this framework, a firm's survival mitigates the opacity of the relationship with lenders; therefore, the provision of external resources becomes easier (La Rocca et al. 2011). In contrast,

3 Although the trade-off theory has been especially criticized for overemphasizing deadweight costs associated with bankruptcy; see (Miller 1977; Myers 1984).

4 A contrasting hypothesis is formulated by Rajan and Zingales (1995) for larger firms. As they are subject to lower information asymmetry, they are encouraged to use equity financing; therefore, a negative relationship between leverage and size is predicted (Rajan and Zingales 1995). 
the theory of the financial life cycle of the firm proposes a non-linear relationship between leverage and age: In the first stage of firms' existence, the demand for external resources is greater because the surviving firms grow faster; this need for external finance decreases in the maturity stage because there are fewer investment opportunities and firms are able to accumulate greater resources to finance their activities (Berger and Udell 1998). Thus, there may be a negative relationship between leverage and age-a relationship that remains negative when one focuses on short-term debt instead of long-term debt (Hall et al. 2004). The empirical evidence is, on that front, not conclusive: Both positive and negative relationships between leverage and age have been found (see, for recent examples, Beattie et al. 2006; Daskalakis and Psillaki 2008; Noulas and Genimakis 2011; La Rocca et al. 2011).

The growth rate of a firm is usually taken as an approximation of investment opportunities; its relationship with leverage is ambiguous. On the one hand, in the trade-off approach, faster growth rates tend to increase distress costs; therefore, self-financing is preferred and the relationship between leverage and growth could consequently be negative (Kraus and Litzenberger 1973). On the other hand, pecking order theory tells us that profitable firms are able to make higher earnings and thus can sustain greater debt costs; therefore, a positive relationship is predicted between leverage and growth (Myers and Majluf 1984). The empirical evidence is compatible with both these approaches as sometimes the relationship is found to be positive and sometimes negative (Rajan and Zingales 1995; Psillaki and Daskalakis 2009; Noulas and Genimakis 2011; La Rocca et al. 2011).

More broadly, the pecking order approach is usually seen in the literature as providing a better explanation of the relationship between leverage and profitability (see Mateev et al. 2013). As external finance is more expensive than internal finance, profitable firms may exhibit a general propensity to use internal resources; consequently, a negative relationship may prevail between leverage and earnings. The relationship becomes unclear in terms of the distinction between short-term debt and long-term debt. Indeed, profitable firms need to finance their growth through external resources because they have greater opportunities and the retained profits are insufficient to finance such growth in the long-run. Consequently, a positive relationship might prevail between earnings and long-term debt, while this relationship might remain negative with regard to short-term debt. The empirical evidence is compatible with all the above arguments; empirical studies generally find that leverage is correlated negatively with the profit rate, but the relationship can be positive or negative for short-term and long-term debt depending on the prevalence of the former or latter (Rajan and Zingales 1995; Adedeji 1998; Michaelas et al. 1999; Hall et al. 2004).

Earnings' volatility is usually taken as a proxy for the riskiness of business operations and for the likelihood of financial distress. A strong relationship can be predicted between leverage and the riskiness of a firm because higher debt causes greater volatility in the firm's earnings. The explanation for this relationship proposed by the pecking order theory is as effective as that of trade-off theory; internal finance is preferred and, consequently, firms reduce their leverage to reduce their cost of capital and to contain their risk. This is because a negative relationship is predicted between leverage and riskiness. Empirical analysis generally confirms this hypothesis (Cassar and Holmes 2003; Hall et al. 2004; Psillaki and Daskalakis 2009).

Finally, among other determinants of capital structure choices, the tangibility of assets, measured by the share of fixed assets to total assets, is of importance because greater fixed assets might make it easier to gain access to external finance. There are two reasons for this: First, with a high share of fixed assets, lenders are able to minimize their loss if bankruptcy occurs; secondly, the collateral of the firm will be larger. Based on these arguments, a positive relationship between asset structure and long-term debt is expected, while the relationship with short-term debt might be negative. Although the direction of the relationship is ambiguous depending on the composition of debt maturity, the available empirical evidence suggests that a positive relationship might prevail between leverage and asset structure; this result is verified effectively with reference to large firms (Demirgüç-Kunt and Maksimovic 1999). However, such a positive relationship has never been confirmed for small firms; according to several studies, the relationship is negative, especially for short-term debt (Rajan and Zingales 1995; Chittenden et al. 1996; Jordan et al. 1998; Michaelas et al. 1999; Frank and Goyal 2003). 
As mentioned in the introduction above, such firm-level determinants were first the object of empirical studies conducted at the country level (usually the United States). It is only gradually, especially after the late 1990s, that economists started empirically testing capital structure theories through cross-country studies. What such studies have found can be summarized thus: On the one hand, firm-level determinants were generally found to hold across countries-in other words, the sign of the relationship between leverage and such firm-level factors was found not to change from one country to the next (see, for instance, Booth et al. 2001); on the other hand, however, these comparative studies have generally found significant cross-country variation in the capital structure of firms. For instance, in a survey of 12,726 SMEs distributed over 28 European countries, Moritz et al. identified eight different clusters or financing patterns (Moritz et al. 2016). Cross-country variation is frequently attributed, either directly or indirectly, to a variety of country-level factors, to which we now turn.

\subsection{From Country-Level Factors to Cross-Regional Variation in Small Firms' Financing Patterns}

Country-level factors have been early identified in the economic literature as belonging to two broad groups: Factors related to countries' legal/institutional environment, on the one hand; and factors related to countries' financial system, on the other. Both sets of factors were first analyzed in the context of studies trying to establish country-level causes of economic growth and development (Levine 1997, 2004), and within the so-called "law and finance" literature (La Porta et al. 1997, 1998). Subsequent works within the capital structure literature have amply drawn on these earlier and more general analyses.

Institutional variables, such as the nature of the legal system (i.e., a common-law versus a civil law system) and the quality of enforcement, are especially relevant because they affect the ability of capital providers to enforce debt contracts (Fan et al. 2012). As a consequence, lower quality law enforcement, measured by some authors as the absence of sound bankruptcy procedures and the perceived existence of corruption (Fan et al. 2012), by others as creditor and shareholder rights protection (De Jong et al. 2008), should be correlated with lower leverage (and, generally, lower access to external finance by firms). On the other hand, however, lower quality institutions may encourage firms to seek alternative sources of finance; as Beck et al. (2008) put it, "in countries with weaker property rights protection, we would expect substitute forms of external finance, such as informal and supplier credit or development bank financing to be used." (Beck et al. 2008, p. 469). The level of economic development is another important country-level factor that may affect firms' capital structure. Here, the empirical findings diverge: Beck et al. (2008) did not find a significant relationship between the level of economic development and small firms' financing patterns (Beck et al. 2008); while Fan et al. (2012), who studied a sample within a narrower set of countries, but over a longer period, found that debt maturity is positively related to levels of economic development (Fan et al. 2012). Finally, the structure and the functioning of a country's financial sector is widely assumed to have consequences on firms' capital structure. The frequently tested hypothesis here is that the greater the size of the banking sector, the greater the firms' leverage; while this hypothesis is confirmed in empirical studies, an additional hypothesis negatively correlating the size of the banking sector with debt maturity has been validated (Fan et al. 2012) and invalidated (Demirgüç-Kunt and Maksimovic 1999).

However, country-level factors do not only affect firms' capital structure directly. As De Jong et al. (2008) usefully pointed out, they also exert an indirect effect by influencing the role of firm-specific determinants of leverage (De Jong et al. 2008). In particular, they argue that "the roles of bankruptcy cost variables, namely tangibility, business risk, and firm size, can be mitigated in a country with a more developed bond market as bankruptcy costs are better handled because of good protection for creditors." (De Jong et al. 2008).

Are there specific country effects regarding SMEs? While earlier studies (Rajan and Zingales 1995; Demirgüç-Kunt and Maksimovic 1999; Booth et al. 2001; De Jong et al. 2008) focused mostly on large firms, it is only recently that systematic cross-country studies of SMEs' financial patterns have been undertaken (Hall et al. 2004; Beck et al. 2008; Mateev et al. 2013). As argued above, the size of the firm 
is a key firm-specific determinant of capital structure. The comparative literature reviewed here has argued that country-level factors may affect small firms differently than large firms. In particular, as Beck et al. argue, "better property right protection can level the playing field between small and large firms in terms of the use of external and especially bank finance." (Beck et al. 2008, p. 482).

A more fine grained understanding of the impact of varying levels and rhythms of institutional and economic development may be gained from another shift in focus, however: Hence, the emergence, in the past decade, of a new stream of studies dedicated to cross-regional comparisons of capital structure choices among SMEs (La Rocca et al. 2010, 2011; Palacín-Sánchez et al. 2013; Serrasqueiro and Caetano 2015; Palacín-Sánchez and Pietro 2016; Di Pietro et al. 2016; Matias and Serrasqueiro 2017). All these studies focus on cross-regional variation in SME financing in three Southern European countries-Italy, Spain, and Portugal. These three countries, furthermore, are characterized by significant cross-regional differences in social and economic development.

The shift in focus accomplished in these studies presents several advantages: First, it can allow us to hold some of the institutional and financial variables identified at the country level constant, since they are not liable to vary across regions of a same country. Such constant factors are: The nature of the legal system (e.g., civil vs. common law). On the other hand, several other country-level institutional and financial variables are easily transposable at the regional level, namely: The quality of legal enforcement (see Guiso et al. 2004, for an analysis of the Italian case), the amount/degree of perceived corruption, and the size and diversity of the banking sector. The size and access of the securities' markets are less relevant at the regional level when focusing on small firms' capital structure, given those firms' assumed little access to national securities market and overall reliance on local financial markets for their funding.

The second advantage is that cross-regional comparisons may highlight within-country distortions in (i) the institutional environment faced by small firms (as seen above) and (ii) the availability and the nature of financial services. Economic geography has shown how the spatial structure of financial systems may influence the availability of funding for small and new firms. Economically lagging regions, in other words, may be less well equipped with financial intermediaries and institutions, thus accentuating the "funding gap" faced by SMEs (Klagge et al. 2017).

What are, then, the main findings of this emerging literature? According to Beck et al., small firms in countries with higher financial development and/or stronger property rights use more external finance (Beck et al. 2008). Is this finding confirmed at the regional level? It does seem so. In a study of a sample of 10,242 Italian SMEs over a 10-year period (until 2005), La Rocca et al. found that, indeed, Southern Italian firms are more constrained financially and less levered (La Rocca et al. 2011). Similar results were found, on a larger sample and over a more recent six-year period, by Di Pietro et al. (2016), who also found that banking concentration at the regional level is negatively related to small firms' leverage. A positive relationship between financial development and small firms' leverage was found by Palacin-Sánchez and Di Pietro for the Spanish case (Palacín-Sánchez and Pietro 2016). All studies concur that there exists significant cross-regional variation in the capital structure of SMEs-at least in countries, such as Italy, Spain, and Portugal.

The present analysis does not directly test the potential effects of institutional and financial variables on cross-regional differences in SME financing. Rather, as spelled out in the Introduction above, the paper aims at contributing to the empirical literature by further establishing the significance of cross-regional variation; and, in particular, by distinguishing between various types of effects the region-level factors discussed above may have on the capital structure of small firms in the Italian context.

\section{Data}

The data set used for the empirical analysis is composed of a large panel of Italian manufacturing firms with between 10 and 249 employees, covering the years, 2001-2013. The data comes from the Italian National Institute of Statistics (ISTAT). Sampled firms are manufacturing firms, extracted from the Italian National Business Register (ASIA) and classified according to the main sectoral activity 
(Isic-Rev.4) at the two-digit level-the 10-33 codes based on the NACE classification of economic activities (which follows the latest Ateco guidelines). The original data were obtained from firms' individual statements; they were completed with additional information regarding, in particular, the date of establishment, equity ownership, the composition of employment, and exports.

The data set was an unbalanced panel because:

(a) Not all firms were present for every year of the period under study; and

(b) not all the individual data were available every year of the period under study.

The panel was initially restricted to SMEs, namely firms with fewer than 250 employees and total balance sheets of less than 43 million Euro in accordance with the EU definition. ${ }^{5}$ This sample included potentially around 570,000 observations.

Two problems made this original panel unsuitable for further analysis. A first problem concerned the extraction of data from firms' statements. Current fiscal regulation allows smaller firms to provide an "abridged balance sheet", which is a simplified statement that enables them to omit certain information that would otherwise be compulsory. For our purposes here, abridged balance sheets only contain data on total liabilities, making it possible to distinguish between short-term and long-term liabilities, but not between types of liabilities, thus making it impossible to identify the amount of financial debt or the amount of bank debt. This limitation prevented us from using conventional leverage measures for many observations. A second issue was related to the period of observation. As is well known, 2007 and 2008 saw the breakout of the global financial and banking crisis, leading to a dramatic fall in firms' turnover. Naturally, corporate financial statements during the latter part of the period under study reflected the consequences of this exceptional event. This created a potential bias for some of the financial ratios used for the empirical analysis, especially profit ratios. To avoid these sources of possible bias, we first removed those firms employing abridged balance sheets from the original data $\operatorname{set}^{6}$ and then, to mitigate the second source of bias, we restricted the analysis only to profitable firms.

Therefore, the final data set was based on the annual average of more than 33,000 firms; for the whole 2001-2013 period, the potential sample comprised more than 427,000 firm-year observations. The Southern SMEs comprise $12.6 \%$ of the total sampled firms, namely around 54,000 firm-year observations (see Table 1 below). In the analysis, the whole sample was broken down in two size classes: (i) Small firms with 10 to 49 employees and total balance sheets of less than 10 million Euro; and (ii) medium-sized firms with 50 to 249 employees and total balance sheets of more than 10 million Euro and less than 43 million Euro. ${ }^{7}$ Around $86 \%$ of the sample comprised small firms. From the last column of Table 1, it appears that the Southern share of sampled firms was $12.6 \%$ of the total number of observed firms; and that the share of small firms was relatively higher compared with the share of medium-sized firms (13.3\% and 9.2\%, respectively).

Table 1. Sample composition for year and for sized classes.

\begin{tabular}{cccc}
\hline & ITALY & SOUTH & \% SOUTH \\
\hline 2001 & 36,978 & 5406 & 14.6 \\
2002 & 35,388 & 4887 & 13.8 \\
2003 & 33,171 & 4396 & 13.3 \\
2004 & 34,227 & 4589 & 13.4 \\
2005 & 34,504 & 4425 & 12.8 \\
2006 & 34,000 & 4428 & 13.0 \\
2007 & 33,261 & 4178 & 12.6 \\
\hline
\end{tabular}

5 The EU recommendation 2003/3061/CE contains the criteria distinguishing micro, small, and medium-sized firms, applied from the year, 2005.

6 The removed observations cover firms with a total of around 80,000 employees; obviously, most of these are very small firms.

7 The latter being the threshold used by EU official bodies to distinguish SMEs from large firms. 
Table 1. Cont.

\begin{tabular}{cccc}
\hline & ITALY & SOUTH & \% SOUTH \\
\hline 2008 & 34,081 & 4145 & 12.2 \\
2009 & 32,437 & 3898 & 12.0 \\
2010 & 30,990 & 3578 & 11.5 \\
2011 & 30,445 & 3542 & 11.6 \\
2012 & 29,379 & 3385 & 11.5 \\
2013 & 28,607 & 3114 & 10.9 \\
\hline SMALL FIRMS & 360,518 & 47,793 & 13.3 \\
MEDIUM FIRMS & 66,950 & 6178 & 9.2 \\
\hline TOTAL SME & 427,468 & 53,971 & 12.6 \\
\hline
\end{tabular}

\section{Methodology}

The analysis proposed here relied on four specifications for (measurements of) the dependent variable, i.e., leverage $(L E V)$ :

(1) Total financial debt/equity (TFD/EQU);

(2) short-term financial debt/equity (SFD/EQU);

(3) long-term financial debt/equity $(L F D / E Q U)$; and

(4) total bank debt/equity (TBD/EQU).

All these dependent variables were measured based on book value. ${ }^{8}$

The explanatory variables were: Size, age, growth, profitability, asset structure, and riskiness. In particular:

(a) Size (SIZE) was approximated by the annual average number of employees (EMPLOYMENT). ${ }^{9}$

(b) Age (AGE) was measured by the number of years from the establishment of the firm to the observation year.

(c) Growth rate (GROWTH) was measured by the annual percentage variation in total assets.

(d) Profitability was expressed by the return on investment (ROI), measured by the gross profit on investment (equity plus total debt). ${ }^{10}$

(e) Asset structure (TANGIBILITY) was the share of fixed assets out of total assets. Fixed assets were measured by the total net fixed assets, i.e., the costs of fixed assets minus accumulated depreciation.

(f) Riskiness (RISK) was approximated by the standard deviation of the profit rates (ROI).

The estimations were based on the full sample (ITALY), as well as on the Mezzogiorno subsample (SOUTH). For the ITALY model, a dummy variable devoted to capturing the differences in leverage for the firms in the Mezzogiorno regions was added:

(a) The regional dummy (REGIONAL DUMMY) was a variable assuming the value 1 for the observations of Southern firms and zero otherwise.

Initially, our analysis was based on the full sample; then, we restricted the analysis to profitable firms to avoid possible biases arising from the dramatic alteration in firms' data caused by the breakout

8 Several studies use both market and book values for the measurement of leverage. The choice to use the book value is generally justified by the argument that the optimal level of leverage depends on the trade-off between the benefits and costs of debt financing. As benefits mostly consist in cash savings arising from the debt tax shield, they can be reliably measured by book values only.

9 Alternative specification of the "size" variable were total sales or total assets. The findings using both total sales or total assets as a proxy for size did not differ significantly from findings using employment; thus, we chose to keep only one specification for size, and decided not to show the estimations with the total sales total assets variables, for the sake of brevity.

10 Preliminary elaborations using different profitability ratios (ROA, ROE) yield findings similar to those examined in the paper; they are not shown here for the sake of brevity. 
of the financial crisis (see the previous section). Therefore, all variables other than profitability were expressed in natural logarithmic form; the estimated coefficients must be interpreted as the elasticity of the variables in relation to firm leverage.

The empirical model was as follows:

$$
\begin{aligned}
& L E V^{s}=\beta^{1} S_{I Z E_{i, j, h}}+\beta^{2} A G E_{i, j, h}+\beta^{3} G R O W_{i, j, h}+\beta^{4} P R O F^{s}{ }_{i, j, h}+\beta^{5} T A N G_{i, j, h}+\beta^{6} R I S K_{i, j, h} \\
& +\beta^{7} R E G_{i, j, h}+\alpha_{i}+\alpha_{j}+\alpha_{h}+\mu_{i, j, h}
\end{aligned}
$$

where $\beta$ coefficients refer to the $i$-th firm of the $h$-th manufacturing industry for the $j$-th year; the peak $s$ indicates the different specifications of the variable and $\alpha_{i}, \alpha_{j}$ and $\alpha_{h}$ are the individual, temporal and industry effects; and $\mu_{i, j, h}$ is the error term.

We estimated a previous fixed effects panel. We addressed the outlier problem by dropping the observations below the 10th percentile and above the 90th percentile for the increasing distribution of the assets.

Generally, the empirical analysis indicates that both the size and the age variables are correlated with the fixed effects. Indeed, in preliminary elaborations, the correlations between the constant term and both the size variables (assets and employment) and the age variables were not negligible. Moreover, the preliminary tests indicated that the effects on leverage of both size and age variables are widely substitutable so that while the size coefficients are highly significant, the age coefficients are not different to zero systematically. Therefore, to address this problem an interaction variable was obtained by scaling the size on age in order to substitute for both of these variables. Therefore, the previous variables SIZE and AGE were substituted by the size-age variable (EMP-AGE INTERACTION).

Based on preliminary estimations, it emerges that the industry effects $\alpha_{h}$ were not always significant, even when statistical acceptance was fixed at below standard levels. This confirms the lack of significant differences in terms of industry impact on firm leverage. ${ }^{12}$ For this reason, the previous empirical model maintains only the very significant temporal effects $\alpha_{j}$ and the individual effects $\left(\alpha_{i}\right)$.

Thus, the final version of the empirical model was:

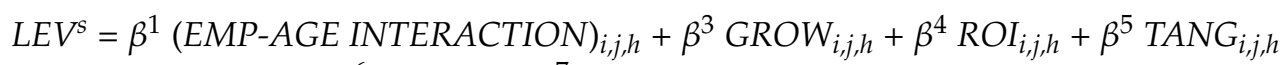

$$
\begin{aligned}
& +\beta^{6} \operatorname{RISK}_{i, j, h}+\beta^{7} R E G_{i, j, h}+\alpha_{i}+\alpha_{j}+\alpha_{h}+\mu_{i, j, h}
\end{aligned}
$$

\section{Descriptive Statistics: Some Distinctive Features of the Financial Structure of Southern Italian SMEs}

As pointed out in the introduction above, the present study aims to highlight the determinants of cross-regional variation in small firms' capital structure by analyzing the evolution of such a capital structure in Southern Italian SMEs over the period of 2001 to 2013. In particular, we focus on the trends regarding the leverage component of SMEs' capital structure: Equity and debt. As mentioned above, such a period is marked by the breakout of the 2007-2008 financial crisis and the ensuing credit crunch, which exacerbated the collapse in output in the following years.

Thus, we broke down the period of observation into two sub-periods: 2001 to 2007 and 2008 to 2013. Table 2 shows the median values of a few equity ratios for the two sub-periods. It can be noted that the equity ratios were generally higher for Southern SMEs than Center-North SMEs; the ratios of equity to value added (EQU/VAD) and to employment (EQU/EMP) were higher, while the equity-asset ratio (EQU/TA) was lower (except for Southern medium-sized firms in the 2008-2013 sub-period). This difference reflects both the higher level of equity in Southern SMEs, and the fact that

12 This finding reaffirms the conclusions of the previous analysis. For example, in a study based on a wide sample of US companies, MacKay and Philips (2005) found that industry effects explain far less of the variation in financial structure than do firm fixed effects. Cassar and Holmes (2003) also found that industry effects have very limited impacts on firm leverage and that they do not improve the explanatory capacity of the model. 
the weight of fixed assets in relation to total assets (FIX/TA) is considerably higher for Southern SMEs than for firms located in other Italian regions. These features appear more marked particularly for medium-sized firms, but they were also notable for small firms.

Table 2. Equity and asset structure ratios for sized classes (median values).

\begin{tabular}{|c|c|c|c|c|c|c|}
\hline & \multicolumn{2}{|c|}{ 2001-2013 } & \multicolumn{2}{|c|}{ 2001-2007 } & \multicolumn{2}{|c|}{$2008-2013$} \\
\hline & ITALY & SOUTH & ITALY & SOUTH & ITALY & SOUTH \\
\hline & \multicolumn{6}{|c|}{ EQU_VAD } \\
\hline SMALL FIRMS & 337.5 & 483.8 & 300.3 & 437.1 & 409.4 & 586.0 \\
\hline MEDIUM FIRMS & 434.9 & 529.6 & 388.4 & 490.8 & 525.1 & 613.3 \\
\hline \multirow[t]{2}{*}{ TOTAL } & 353.1 & 490.1 & 314.8 & 445.8 & 427.5 & 580.6 \\
\hline & \multicolumn{6}{|c|}{ EQU/EMP } \\
\hline SMALL FIRMS & 3830.0 & 5139.3 & 3108.6 & 4260.3 & 5078.4 & 6765.0 \\
\hline MEDIUM FIRMS & 5620.3 & 5994.6 & 4531.7 & 5018.3 & 7539.6 & 7857.3 \\
\hline \multirow[t]{2}{*}{ TOTAL } & 4106.4 & 5236.6 & 3328.4 & 4651.4 & 5463.2 & 5893.6 \\
\hline & \multicolumn{6}{|c|}{ EQU/TA } \\
\hline SMALL FIRMS & 71.4 & 68.7 & 74.1 & 70.3 & 67.6 & 66.2 \\
\hline MEDIUM FIRMS & 69.9 & 69.2 & 73.0 & 71.1 & 65.5 & 66.4 \\
\hline \multirow[t]{2}{*}{ TOTAL } & 71.1 & 68.8 & 73.9 & 70.4 & 67.2 & 66.2 \\
\hline & \multicolumn{6}{|c|}{ FIX/TA } \\
\hline SMALL FIRMS & 19.1 & 29.7 & 17.4 & 28.6 & 17.4 & 28.6 \\
\hline MEDIUM FIRMS & 21.8 & 31.2 & 19.6 & 29.1 & 20.2 & 30.6 \\
\hline TOTAL & 19.7 & 29.9 & 20.2 & 28.7 & 18.0 & 29.1 \\
\hline
\end{tabular}

Legend: EQU_VAD = Equity/Value Added; EQU_EMP = Equity/Number of Employees; EQU/TA = Equity/Total Assets; FIX/TA = Fixed Assets/Total Assets.

This situation is in stark contrast with the widespread notion that firms in less advanced regions are under-capitalized. Indeed, the findings of this study reinforce the results of previous studies concerning Southern Italian firms, whereby the latter appear oversized compared to their levels of activity, i.e., there is an excess of production capacity. ${ }^{13}$ Whether this is due to the presence of financial incentives to undertake fixed investments or to accounting constraints related to product markets, the magnitude of this over-capacity cannot entirely be explained by the likely high significance of the informal economy within the sphere of activity of Southern SMEs.

With regard to debt, Table 3 below shows the median values of a few debt indicators. Descriptive statistics confirm the higher indebtedness of Southern Italian SMEs, in contrast with the existing literature (La Rocca et al. 2010, 2011). The total financial debt to value added ratio (TFD/VAD) was notably higher in Southern firms, while the debt-equity ratio (TFD/EQU) was lower. Although banks were the main source of debt funding, the share of bank debt to total financial debt (TBD/TFD) was not very high. It can be noted that the weight of short-term debt (SFD/TFD) was unexpectedly lower than for other firms and the fact that the share of long-term debt was consequently higher contrasts with the composition of debt shown in studies covering previous periods. ${ }^{14}$

It is possible to infer from Table 3 that over-indebtedness was especially significant for the smaller firms in Southern Italy; in addition, while their debt-to-value added ratio was relatively higher than

13 On the basis of wide representative samples of manufacturing firms, previous studies have shown that the equity-to-assets ratios is systematically higher in Southern Italian firms than in other Italian regions (see, for instance, Mediocredito 1997, 2000; Capitalia 2002).

14 The surveys cited above show that in previous periods, Southern Italian manufacturing firms exhibited a greater share of short-term debt and a lower share of long-term debt than firms in other Italian regions (Mediocredito 1997, 2000; Capitalia 2002). 
other classes of firms, their debt-to-equity ratio was lower-due, as explained above, to a higher level of equity. The other measures shown in Table 3, which relate to bank debt and short-term debt, confirm that small Southern firms have especially suffered from the consequences of the post-2007 crisis credit crunch in the final years of the period under study; thus, the relative distance from firms of similar size located in other Italian regions increased.

Table 3. Debt ratios for sized classes (median values).

\begin{tabular}{|c|c|c|c|c|c|c|}
\hline & \multicolumn{2}{|c|}{$2001-2013$} & \multicolumn{2}{|c|}{ 2001-2007 } & \multicolumn{2}{|c|}{$2008-2013$} \\
\hline & ITALY & SOUTH & ITALY & SOUTH & ITALY & SOUTH \\
\hline & \multicolumn{6}{|c|}{ TFD/VAD } \\
\hline SMALL FIRMS & 372.4 & 506.3 & 381.6 & 492.3 & 356.5 & 519.1 \\
\hline MEDIUM FIRMS & 482.3 & 654.9 & 501.3 & 668.0 & 448.3 & 637.7 \\
\hline \multirow[t]{2}{*}{ TOTAL } & 387.2 & 523.3 & 398.0 & 509.2 & 368.7 & 551.1 \\
\hline & \multicolumn{6}{|c|}{ TFD/EQU } \\
\hline SMALL FIRMS & 108.5 & 102.9 & 126.3 & 111.5 & 126.3 & 111.5 \\
\hline MEDIUM FIRMS & 112.4 & 118.1 & 130.2 & 127.6 & 93.8 & 105.9 \\
\hline \multirow[t]{2}{*}{ TOTAL } & 109.8 & 104.6 & 126.9 & 113.4 & 89.5 & 94.0 \\
\hline & \multicolumn{6}{|c|}{ SFD/DFT } \\
\hline SMALL FIRMS & 91.2 & 85.5 & 92.7 & 88.0 & 92.7 & 89.1 \\
\hline MEDIUM FIRMS & 78.7 & 75.9 & 79.6 & 76.8 & 77.0 & 74.1 \\
\hline \multirow[t]{2}{*}{ TOTAL } & 89.0 & 83.9 & 90.4 & 86.2 & 87.0 & 80.2 \\
\hline & \multicolumn{6}{|c|}{ TBD/TFD } \\
\hline SMALL FIRMS & 47.9 & 43.2 & 49.1 & 43.1 & 46.4 & 43.4 \\
\hline MEDIUM FIRMS & 58.3 & 61.0 & 61.3 & 63.3 & 54.2 & 58.2 \\
\hline TOTAL & 49.6 & 45.4 & 51.1 & 45.8 & 47.7 & 45.0 \\
\hline
\end{tabular}

Legend: TFD/VAD = Total Financial Debts/Value Added; TFD/EQU = Total Financial debts/Equity; SFD/DFT = Short-term Financial Debts/Total Financial Debts; TBD/TFD = Total Bank Debts/Total Financial Debt.

\section{Results of Empirical Analysis}

Table 4 below presents the statistics of all variables.

The OLS estimates for this unbalanced fixed-effects panel based on both the ITALY and SOUTH samples are shown in Table 5 below; the table presents the outcomes of the different empirical models with both the values and natural logarithms of the ROI variables.

We can stress that although coefficient values were very different, most of the directions for the relationships remained unchanged for the ROI value regression and the ROI logarithmically transformed regression. There was a positive relationship between leverage and growth; and leverage and the size-age interaction variable. While the former confirms theoretical predictions, the latter relationship does not and probably indicate the predominance of the size effect, which was expected to be positive, over the age effect, which might be ambiguous. Moreover, the relationships between the various measures of leverage and the asset structure variable, i.e., the ratio of fixed assets to total assets, were negative, an exception being the long-term leverage, which was positively related to the asset structure. This relationship, however, concerns the whole Italian sample. In the case of Southern SMEs, by contrast, the relationship between asset structure and leverage was systematically negative. While a positive relationship between asset structure and long-term debt leverage was expected because fixed assets can be used as collateral, for short-term debt leverage, a negative relationship should prevail. Therefore, the outcomes can be interpreted as the prevalence of this latter effect over the former, associated with the uses of collateral. 
Table 4. Main statistics for firm-level variables.

\begin{tabular}{|c|c|c|c|c|c|c|c|c|c|c|c|}
\hline & \multicolumn{5}{|c|}{ ITALY } & \multicolumn{6}{|c|}{ SOUTH } \\
\hline & AVERAGE & ST. DEV. & MIN. & MAX. & $\mathbf{N}^{\circ}$ OBS & & AVERAGE & ST. DEV. & MIN. & MAX. & $\mathrm{N}^{\circ} \mathrm{OBS}$ \\
\hline \multicolumn{7}{|c|}{ SMEs } & \multicolumn{5}{|c|}{ SMEs } \\
\hline SIZE & 29.5 & 36.5 & 0.5 & 249.9 & 427,468 & SIZE & 24.5 & 31.4 & 0.5 & 249.7 & 53,971 \\
\hline AGE & 31.8 & 11.7 & 6.0 & 182.0 & 427,468 & AGE & 28.3 & 10.5 & 11.0 & 113.0 & 53,971 \\
\hline GROWTH & 4.6 & 1.1 & -6.8 & 7.1 & 218,880 & GROWTH & 4.6 & 1.1 & -3.9 & 6.7 & 24,548 \\
\hline ROI & 4.1 & 120.7 & $-65,839.9$ & $24,814.9$ & 427,468 & ROI & 0.7 & 95.7 & -4346.7 & $17,919.7$ & 53,971 \\
\hline TANGIBILITY & 21.5 & 19.9 & 0.0 & 99.8 & 427,468 & TANGIBILITY & 32.5 & 21.9 & 0.0 & 99.6 & 53,971 \\
\hline RISK & 5.3 & 75.8 & 0.0 & 46.5 & 424,680 & RISK & 4.8 & 34.4 & 0.0 & 6166.6 & 52,315 \\
\hline \multicolumn{7}{|c|}{ SMALL FIRMS (10-49 employees) } & \multicolumn{5}{|c|}{ SMALL FIRMS (10-49 employees) } \\
\hline SIZE & 16.8 & 11.8 & 0.5 & 49.9 & 360,518 & SIZE & 15.4 & 11.6 & 0.5 & 50.0 & 47,793 \\
\hline AGE & 30.9 & 11.3 & 12.0 & 182.0 & 360,518 & AGE & 27.9 & 10.0 & 12.0 & 113.0 & 47,793 \\
\hline GROWTH & 4.5 & 1.1 & -6.8 & 7.1 & 161,557 & GROWTH & 4.1 & 1.0 & -2.6 & 6.1 & 19,108 \\
\hline ROI & 4.3 & 130.8 & $-65,839.9$ & $24,814.9$ & 360,518 & ROI & 0.5 & 99.8 & -4346.7 & $17,919.7$ & 47,793 \\
\hline TANGIBILITY & 24.6 & 20.5 & 0.0 & 99.8 & 360,518 & TANGIBILITY & 32.4 & 22.5 & 0.0 & 99.6 & 47,793 \\
\hline RISK & 5.5 & 85.4 & 0.0 & $46,544.9$ & 357,883 & RISK & 5.0 & 36.4 & 0.0 & 6116.6 & 46,715 \\
\hline \multicolumn{7}{|c|}{ MEDIUM SIZED FIRMS (50-249 employees) } & \multicolumn{5}{|c|}{ MEDIUM SIZED FIRMS (50-249 employees) } \\
\hline SIZE & 98.8 & 46.7 & 50.0 & 249.9 & 66,950 & SIZE & 94.8 & 44.5 & 50.0 & 249.7 & 6178 \\
\hline AGE & 36.7 & 12.5 & 6.0 & 182.0 & 66,950 & AGE & 32.1 & 12.9 & 11.0 & 88.0 & 6178 \\
\hline GROWTH & 5.1 & 0.9 & -3.8 & 7.0 & 57,323 & GROWTH & 5.2 & 0.9 & -1.3 & 6.7 & 5440 \\
\hline ROI & 2.6 & 27.8 & -2426.1 & 3182.3 & 66,950 & ROI & 2.0 & 57.0 & -268.1 & 3182.3 & 6178 \\
\hline TANGIBILITY & 24.3 & 16.3 & 0.0 & 95.5 & 66,950 & TANGIBILITY & 32.5 & 16.8 & 0.0 & 95.0 & 6178 \\
\hline RISK & 4.1 & 10.6 & 0.0 & 1718.6 & 66,950 & RISK & 3.8 & 9.5 & 0.0 & 458.7 & 6140 \\
\hline
\end{tabular}


Relationships between leverage and the profit rate and the volatility variables have opposite signs in the different regressions. The relationship was systematically negative in the ROI logarithm regression, as expected; it was also negative for the ITALY regression using ROI values, with the exception of the relationship with long-term debt leverage. By contrast, it was unexpectedly positive or close to zero for Southern firms, with the exception of short-term debt leverage. The relationships between the various leverage measures and the risk variable showed an unexpected positive relationship for the ROI value regression and a negative relationship as expected for the ROI logarithmic regression.

Finally, when we examined the regional dummy for the ITALY model, some outcomes appeared quite clear, even though the coefficients were not always significant at the conventional level. The effect on total leverage as measured by total debts over equity (TFD/EQU) was notably lower for Southern firms compared to other Italian firms; this is explained by the reduced impact on short-term debt leverage (SFD/EQU), while the effect on long-term debt leverage (LDF/EQU) appears negligible or ambiguous. There were contrasting results for Southern firms with regard to the effect on bank debt leverage (TBD/EQU) because the ROI value regression was lower for Southern firms, but higher for the ROI transformed regression. The latter finding was as expected because Southern firms exhibit greater dependence on bank resources, being less able to resort to alternative sources of funding ${ }^{15}$.

So far the analysis has borne on the directions or sign of the relationships between the various leverage measures and the explanatory variables. Upon analyzing the estimated coefficients, several significant differences appeared between the national and the regional model. While differences in the impact of other variables on leverage can be viewed as negligible, the main difference concerns the effect of variables measuring profitability and its volatility. The inverse relationship indicating the substitution effect of the profit variable on debt for the Southern firms was not systematically proven and the effect of the risk variable was unexpectedly smaller. Naturally, it was difficult to establish how important these differences are in the comparative analysis; the evidence suggests that individual effects were of considerable importance in the empirical models, but so were the omitted variables when the relative magnitude of the constants was considered.

Table 6 below presents the estimations for the size classes distinguishing small firms from medium-sized firms. These used the logarithmically transformed variables only. Two considerations should be made here. First, the empirical findings for small firms are perfectly consistent with those for firms in the whole sample. Relationships between the leverage ratios and explanatory variables had identical signs and the coefficients were convergent. The Southern regional model shows notable differences with respect to the national model, mirroring the picture arising previously from the comparison with the full sample findings. The dummy variable tells us that the elasticity in the leverage measures for small Southern firms is lower compared to that for small Italian firms, besides that for bank debt leverage; this confirms that small Southern firms are more dependent on bank debt than small firms in other Italian regions.

Second, the regression findings for the medium-sized firm subsample validates the view that the empirical model for small firms also holds for medium-sized firms, i.e., the determinants that explain the choices concerning capital structure for larger firms are effective in explaining the choices of small firms. This was particularly true for both the total financial debt (TFD/EQU) and short-term debt leverage (SFD/EQU) models, but not for the long-term debt level (LFD/EQU) model because of the possibility that medium firms resort to alternative sources of finance. The notable difference arising from the empirical bank debt (TBD/EQU) model does not concern the direction as much as the statistical acceptance of the relationship; in the case of the medium-sized firm model for Italy, the relationship was as expected, whereas for southern firms it was not.

15 It is useful to remind ourselves that from in the studies previously cited, the ratio of total financial debt to equity for Southern firms was, in the 1990s, around 80\%; and it was lower by around 10\% than that for firms located in other regions. In particular, the ratio of bank debt to equity was below $65 \%$; and the difference with firms in the other Italian regions rapidly decreased at the end of the decade to around 10\% (see survey by Mediocredito 2000). 
Table 5. Panel estimation for ITALY and SOUTH [2001-2013 years].

\begin{tabular}{|c|c|c|c|c|c|c|c|c|c|c|c|c|c|c|c|c|}
\hline & \multicolumn{8}{|c|}{ ALL FIRMS (Absolute Values of Variable) } & \multicolumn{8}{|c|}{ PROFITABLE FIRMS (Natural Logarithm Transformed Variable) } \\
\hline & \multicolumn{4}{|c|}{ ITALY } & \multicolumn{4}{|c|}{ SOUTH } & \multicolumn{4}{|c|}{ ITALY } & \multicolumn{4}{|c|}{ SOUTH } \\
\hline & [1] & [2] & [3] & [4] & [1] & [2] & [3] & [4] & [1] & [2] & [3] & [4] & [1] & [2] & [3] & [4] \\
\hline & DFT/EQU & SFD/EQU & LFD/EQU & DBT/EQU & DFT/EQU & SFD/EQU & $\mathrm{LFD} / \mathrm{EQU}$ & DBT/EQU & DFT/EQU & $\mathrm{SFD} / \mathrm{EQU}$ & LFD/EQU & $\mathrm{DBT} / \mathrm{EQU}$ & DFT/EQU & $\mathrm{SFD} / \mathrm{EQU}$ & LFD/EQU & $\mathrm{DBT} / \mathrm{EQU}$ \\
\hline $\begin{array}{c}\text { SIZE-AGE } \\
\text { INTERACTION }\end{array}$ & $\begin{array}{c}0.003 \\
(0.000)^{* * * *}\end{array}$ & $\begin{array}{c}0.002 \\
(0.000)^{* * *}\end{array}$ & $\begin{array}{c}0.001 \\
(0.000)^{* * *}\end{array}$ & $\begin{array}{c}0.004 \\
(0.000)^{* * *}\end{array}$ & $\begin{array}{c}0.006 \\
(0.001)^{* * *}\end{array}$ & $\begin{array}{c}0.003 \\
(0.001)^{* * *}\end{array}$ & $\begin{array}{c}000 \\
(0.000)^{* * *}\end{array}$ & $\begin{array}{c}0.007 \\
(0.001)^{* * *}\end{array}$ & $\begin{array}{c}0.035 \\
(0.002)^{* * *}\end{array}$ & $\begin{array}{c}0.029 \\
(0.003)^{* * * *}\end{array}$ & $\begin{array}{c}0.044 \\
(0.005)^{* * *}\end{array}$ & $\begin{array}{c}0.051 \\
(0.005)^{* * *}\end{array}$ & $\begin{array}{c}0.033 \\
(0.005)^{* * *}\end{array}$ & $\begin{array}{c}0.033 \\
(0.006)^{* * *}\end{array}$ & $\begin{array}{c}0.021 \\
(0.011) *\end{array}$ & $\begin{array}{c}0.085 \\
(0.010)^{* * *}\end{array}$ \\
\hline GROWTH & $\begin{array}{c}3.258 \\
(0.302)^{* * *} \\
\end{array}$ & $\begin{array}{c}2.478 \\
(0.268)^{* * *} \\
\end{array}$ & $\begin{array}{c}0.881 \\
(0.102)^{* * *} \\
\end{array}$ & $\begin{array}{c}2.762 \\
(0.231)^{* * *} \\
\end{array}$ & $\begin{array}{c}1.945 \\
(0.773)^{* *} \\
\end{array}$ & $\begin{array}{c}0.437 \\
(0.679) \\
\end{array}$ & $\begin{array}{c}1.459 \\
(0.288)^{* * *} \\
\end{array}$ & $\begin{array}{c}1.767 \\
(0.557)^{* * *} \\
\end{array}$ & $\begin{array}{c}0.019 \\
(0.002) * * * \\
\end{array}$ & $\begin{array}{c}0.016 \\
(0.003)^{* * * *} \\
\end{array}$ & $\begin{array}{c}0.031 \\
(0.006)^{* * *} \\
\end{array}$ & $\begin{array}{c}0.027 \\
(0.006)\end{array}$ & $\begin{array}{c}0.034 \\
(0.007)^{* * * *} \\
\end{array}$ & $\begin{array}{l}-0.015 \\
(0.008)^{*}\end{array}$ & $\begin{array}{c}0.067 \\
(0.017)^{* * *} \\
\end{array}$ & $\begin{array}{c}0.046 \\
(0.016)^{* * *} \\
\end{array}$ \\
\hline ROI & $\begin{array}{c}-0.040 \\
(0.003)^{* * *}\end{array}$ & $\begin{array}{c}-0.032 \\
(0.003)^{* * *}\end{array}$ & $\begin{array}{c}-0.008 \\
(0.001)^{* * *}\end{array}$ & $\begin{array}{c}-0.026 \\
(0.003)^{* * *}\end{array}$ & $\begin{array}{c}-0.060 \\
(0.014)^{* * * *}\end{array}$ & $\begin{array}{c}-0.039 \\
(0.012) * * *\end{array}$ & $\begin{array}{c}-0.021 \\
(0.005)^{* * * *}\end{array}$ & $\begin{array}{c}-0.215 \\
(0.010) * * *\end{array}$ & $\begin{array}{c}-0.017 \\
(0.002)^{* * *}\end{array}$ & $\begin{array}{c}-0.035 \\
(0.002)^{* * *}\end{array}$ & $\begin{array}{c}0.029 \\
(0.004)^{* * *}\end{array}$ & $\begin{array}{c}-0.065 \\
(0.004)^{* * *}\end{array}$ & $\begin{array}{c}0.007 \\
(0.005)\end{array}$ & $\begin{array}{c}-0.016 \\
(0.006)^{* * *}\end{array}$ & $\begin{array}{c}0.062 \\
(0.011)^{* * *}\end{array}$ & $\begin{array}{c}0.001 \\
(0.011)\end{array}$ \\
\hline $\begin{array}{c}\text { ASSET } \\
\text { TANGIBILITY } \\
\end{array}$ & $\begin{array}{c}-1.055 \\
(0.024)^{* * *}\end{array}$ & $\begin{array}{c}-1.138 \\
(0.021)^{* * *}\end{array}$ & $\begin{array}{c}0.084 \\
(0.008)^{* * *} \\
\end{array}$ & $\begin{array}{c}-0.643 \\
(0.019)^{* * *} \\
\end{array}$ & $\begin{array}{c}-1.074 \\
(0.058)^{* * *} \\
\end{array}$ & $\begin{array}{c}-1.062 \\
(0.051)^{* * *} \\
\end{array}$ & $\begin{array}{l}-0.205 \\
(0.021) \\
\end{array}$ & $\begin{array}{c}-0.536 \\
(0.042)^{* * *} \\
\end{array}$ & $\begin{array}{c}-0.007 \\
(0.000)^{* * *}\end{array}$ & $\begin{array}{c}-0.012 \\
(0.000)^{* * *}\end{array}$ & $\begin{array}{c}0.002 \\
(0.000)^{* *} \\
\end{array}$ & $\begin{array}{c}-0.004 \\
(0.000) * * * \\
\end{array}$ & $\begin{array}{c}-0.009 \\
(0.001)^{* * * *} \\
\end{array}$ & $\begin{array}{c}-0.014 \\
(0.001)^{* * *} \\
\end{array}$ & $\begin{array}{c}-0.005 \\
(0.001)^{* * *} \\
\end{array}$ & $\begin{array}{c}-0.003 \\
(0.001)^{* *} \\
\end{array}$ \\
\hline RISK & $\begin{array}{c}0.101 \\
(0.021)^{* * *} \\
\end{array}$ & $\begin{array}{c}0.101 \\
(0.019)^{* * *} \\
\end{array}$ & $\begin{array}{c}0.000 \\
(0.000) \\
\end{array}$ & $\begin{array}{c}0.044 \\
(0.016)^{* * *} \\
\end{array}$ & $\begin{array}{c}0.052 \\
(0.037) \\
\end{array}$ & $\begin{array}{c}0.031 \\
(0.032) \\
\end{array}$ & $\begin{array}{c}0.021 \\
(0.014) \\
\end{array}$ & $\begin{array}{c}0.014 \\
(0.027) \\
\end{array}$ & $\begin{array}{c}-0.020 \\
(0.002)^{* * *}\end{array}$ & $\begin{array}{c}-0.015 \\
(0.002) \\
* * * * \\
\end{array}$ & $\begin{array}{c}-0.026 \\
(0.004)^{* * *} \\
\end{array}$ & $\begin{array}{c}-0.039 \\
(0.004)^{* * *}\end{array}$ & $\begin{array}{l}-0.014 \\
(0.005)^{* *} \\
\end{array}$ & $\begin{array}{l}-0.006 \\
(0.006) \\
\end{array}$ & $\begin{array}{l}-0.020 \\
(0.012)^{*}\end{array}$ & $\begin{array}{c}-0.029 \\
(0.011)^{* * *} \\
\end{array}$ \\
\hline $\begin{array}{l}\text { REGIONAL } \\
\text { DUMMY }\end{array}$ & $\begin{array}{l}-15.230 \\
(6.367)^{* *}\end{array}$ & $\begin{array}{l}-14.996 \\
(8.635)^{* *} \\
\end{array}$ & $\begin{array}{c}0.005 \\
(2.138) \\
\end{array}$ & $\begin{array}{l}-2.851 \\
(3.855) \\
\end{array}$ & & & & & $\begin{array}{c}-0.060 \\
(.057) \\
\end{array}$ & $\begin{array}{l}-0.102 \\
(0.052)^{*}\end{array}$ & $\begin{array}{c}0.120 \\
(0.132) \\
\end{array}$ & $\begin{array}{c}0.023 \\
(0.124) \\
\end{array}$ & & & & \\
\hline$R^{2}$ within & 0.040 & 0.038 & 0.0165 & 0.048 & 0.029 & 0.027 & 0.012 & 0.049 & 0.113 & 0.117 & 0.028 & 0.056 & 0.058 & 0.063 & 0.022 & 0.040 \\
\hline between & 0.018 & 0.038 & 0.011 & 0.008 & 0.026 & 0.045 & 0.001 & 0.013 & 0.003 & 0.015 & 0.006 & 0.000 & 0.008 & 0.030 & 0.004 & 0.001 \\
\hline overall & 0.015 & 0.029 & 0.014 & 0.011 & 0.026 & 0.044 & 0.002 & 0.025 & 0.008 & 0.019 & 0.009 & 0.006 & 0.010 & 0.032 & 0.005 & 0.008 \\
\hline $\mathrm{F}$ & 466.6 & 457.6 & 180.5 & 570.5 & 43.4 & 41.3 & 19.3 & 75.3 & 854.1 & 893.9 & 130.7 & 333.1 & 46.3 & 50.3 & 13.0 & 27.5 \\
\hline $\mathrm{F}\left(\right.$ for all $\left.\mathrm{u}_{\mathrm{i}}\right)$ & 16.6 & 15.8 & 11.7 & 16.1 & 14.3 & 13.9 & 10.8 & 13.0 & 23.2 & 19.4 & 10.6 & 12.3 & 19.2 & 15.3 & 10.1 & 10.2 \\
\hline OBS & 217,895 & 217,895 & 217,895 & 217,895 & 27,412 & 27,412 & 27,412 & 27,412 & 140,281 & 141,236 & 98,936 & 118,920 & 15,398 & 15,339 & 11,966 & 13,881 \\
\hline GROUPS & 38,663 & 38,663 & 38,663 & 38,663 & 5275 & 5275 & 5275 & 5275 & 32,784 & 33,114 & 26,306 & 29,786 & 4065 & 4055 & 3356 & 3745 \\
\hline
\end{tabular}

$\mathrm{t}$-Student in parentheses; significance indicated as follows: ${ }^{* * *} 0.01,{ }^{* *} 0.05,{ }^{*} 0.1$. 
Table 6. Panel estimation (2001-2013 years) for small and medium sized firms (all variables expressed as natural logarithm).

\begin{tabular}{|c|c|c|c|c|c|c|c|c|c|c|c|c|c|c|c|c|}
\hline & \multicolumn{8}{|c|}{ SMALL FIRMS (10-49 Employees) } & \multicolumn{8}{|c|}{ MEDIUM SIZED FIRMS (50-249 Employees) } \\
\hline & \multicolumn{4}{|c|}{ ITALY } & \multicolumn{4}{|c|}{ SOUTH } & \multicolumn{4}{|c|}{ ITALY } & \multicolumn{4}{|c|}{ SOUTH } \\
\hline & [1] & [2] & [3] & [4] & [1] & [2] & [3] & [4] & [1] & [2] & [3] & [4] & [1] & [2] & [3] & [4] \\
\hline & DFT/EQU & SFD/EQU & LFD/EQU & $\mathrm{DBT} / \mathrm{EQU}$ & $\mathrm{DFT} / \mathrm{EQU}$ & SFD/EQU & LFD/EQU & DBT/EQU & DFT/EQU & SFD/EQU & LFD/EQU & DBT/EQU & DFT/EQU & SFD/EQU & LFD/EQU & DBT/EQU \\
\hline $\begin{array}{l}\text { SIZE.-AGE } \\
\text { INTERACTION }\end{array}$ & $\begin{array}{c}0.035 \\
(0.002)^{* * *} \\
\end{array}$ & $\begin{array}{c}0.027 \\
(0.003)^{* * *} \\
\end{array}$ & $\begin{array}{c}0.055 \\
(0.007)^{* * *}\end{array}$ & $\begin{array}{c}0.050 \\
(0.009)^{* * *}\end{array}$ & $\begin{array}{c}0.026 \\
(0.006)^{* * *}\end{array}$ & $\begin{array}{c}0.028 \\
(0.007)^{* * *}\end{array}$ & $\begin{array}{c}0.038 \\
(0.013)^{* * * *}\end{array}$ & $\begin{array}{c}0.085 \\
(0.011)^{* * *}\end{array}$ & $\begin{array}{c}0.026 \\
(0.006)^{* * *}\end{array}$ & $\begin{array}{c}0.027 \\
(0.003)^{* * *}\end{array}$ & $\begin{array}{c}0.003 \\
(0.014) \\
\end{array}$ & $\begin{array}{c}0.061 \\
(0.018)^{* * *}\end{array}$ & $\begin{array}{c}0.041 \\
(0.017)^{* *}\end{array}$ & $\begin{array}{c}0.049 \\
(0.018)^{* * *}\end{array}$ & $\begin{array}{l}-0.048 \\
(0.048)\end{array}$ & $\begin{array}{c}0.162 \\
(0.049)^{* * *}\end{array}$ \\
\hline GROWTH & $\begin{array}{c}0.019 \\
(0.002)^{* * * *}\end{array}$ & $\begin{array}{c}0.015 \\
(0.003)^{* * * *}\end{array}$ & $\begin{array}{c}0.035 \\
(0.007)^{* * * *}\end{array}$ & $\begin{array}{c}0.025 \\
(0.006)^{* * *}\end{array}$ & $\begin{array}{c}0.034 \\
(0.008)^{* * *}\end{array}$ & $\begin{array}{c}0.013 \\
(0.091)\end{array}$ & $\begin{array}{c}0.069 \\
(0.017)^{* * * *}\end{array}$ & $\begin{array}{c}0.041 \\
(0.016)^{* * * *}\end{array}$ & $\begin{array}{c}0.019 \\
(0.006)^{* * *}\end{array}$ & $\begin{array}{c}0.022 \\
(0.007)^{* * *}\end{array}$ & $\begin{array}{c}0.022 \\
(0.013) *\end{array}$ & $\begin{array}{c}0.033 \\
(0.016)^{* *}\end{array}$ & $\begin{array}{c}0.026 \\
(0.019)\end{array}$ & $\begin{array}{c}0.027 \\
(0.019)\end{array}$ & $\begin{array}{c}0.071 \\
(0.051)\end{array}$ & $\begin{array}{c}0.051 \\
(0.053)\end{array}$ \\
\hline ROI & $\begin{array}{c}-0.069 \\
(0.002)^{* * *}\end{array}$ & $\begin{array}{c}-0.024 \\
(0.002)^{* * * *}\end{array}$ & $\begin{array}{c}0.038 \\
(0.005)^{* * * *}\end{array}$ & $\begin{array}{c}-0.049 \\
(0.004)^{* * *}\end{array}$ & $\begin{array}{c}0.012 \\
(0.006)\end{array}$ & $\begin{array}{c}-0.014 \\
(0.007)^{* *}\end{array}$ & $\begin{array}{c}0.077 \\
(0.013)^{* * * *}\end{array}$ & $\begin{array}{c}0.013 \\
(0.011)\end{array}$ & $\begin{array}{c}-0.044 \\
(0.003)^{* * *}\end{array}$ & $\begin{array}{c}-0.058 \\
(0.004)^{* * *}\end{array}$ & $\begin{array}{c}0.004 \\
(0.007)\end{array}$ & $\begin{array}{c}-0.103 \\
(0.009)^{* * * *}\end{array}$ & $\begin{array}{c}-0.021 \\
(0.010)^{* *}\end{array}$ & $\begin{array}{c}-0.028 \\
(0.011)^{* * *}\end{array}$ & $\begin{array}{c}0.027 \\
(0.028)\end{array}$ & $\begin{array}{l}-0.041 \\
(0.029)\end{array}$ \\
\hline $\begin{array}{c}\text { ASSET } \\
\text { TANGIBILITY }\end{array}$ & $\begin{array}{c}-0.007 \\
(0.000)^{* * *}\end{array}$ & $\begin{array}{c}-0.012 \\
(0.000)^{* * *}\end{array}$ & $\begin{array}{c}0.002 \\
(0.000)^{* *}\end{array}$ & $\begin{array}{c}-0.004 \\
(0.000)^{* * *}\end{array}$ & $\begin{array}{c}-0.008 \\
(0.001)^{* * *}\end{array}$ & $\begin{array}{c}-0.014 \\
(0.001)^{* * *}\end{array}$ & $\begin{array}{c}-0.006 \\
(0.001)^{* * *}\end{array}$ & $\begin{array}{c}-0.003 \\
(0.001)^{* *}\end{array}$ & $\begin{array}{c}-0.008 \\
(0.000)^{* * *}\end{array}$ & $\begin{array}{c}-0.012 \\
(0.000)^{* * *}\end{array}$ & $\begin{array}{c}0.001 \\
(0.001)\end{array}$ & $\begin{array}{l}-0.027 \\
(0.001)^{* *}\end{array}$ & $\begin{array}{c}-0.015 \\
(0.001)^{* * *}\end{array}$ & $\begin{array}{c}-0.018 \\
(0.001)^{* * *}\end{array}$ & $\begin{array}{l}-0.001 \\
(0.004)\end{array}$ & $\begin{array}{c}0.000 \\
(0.004)\end{array}$ \\
\hline RISK & $\begin{array}{c}-0.022 \\
(0.002) * * * \\
\end{array}$ & $\begin{array}{c}-0.017 \\
(0.002)^{* * *}\end{array}$ & $\begin{array}{c}-0.024 \\
(0.006)^{* * *}\end{array}$ & $\begin{array}{c}-0.043 \\
(0.005)^{* * *}\end{array}$ & $\begin{array}{l}-0.011 \\
(0.006)^{*}\end{array}$ & $\begin{array}{l}-0.003 \\
(0.007) \\
\end{array}$ & $\begin{array}{l}-0.005 \\
(0.013) \\
\end{array}$ & $\begin{array}{c}-0.024 \\
(0.012)^{* *} \\
\end{array}$ & $\begin{array}{c}-0.014 \\
(0.004)^{* * *}\end{array}$ & $\begin{array}{c}-0.009 \\
(0.004)^{* *}\end{array}$ & $\begin{array}{c}-0.031 \\
(0.008)^{* * *}\end{array}$ & $\begin{array}{l}-0.023 \\
(0.010)^{* *}\end{array}$ & $\begin{array}{c}-0.033 \\
(0.011)^{* *}\end{array}$ & $\begin{array}{l}-0.017 \\
(0.012) \\
\end{array}$ & $\begin{array}{l}-0.092 \\
(0.030) \\
\end{array}$ & $\begin{array}{c}-0.059 \\
(0.092)^{*} \\
\end{array}$ \\
\hline $\begin{array}{l}\text { REGIONAL } \\
\text { DUMMY }\end{array}$ & $\begin{array}{c}-0.186 \\
(0.083)\end{array}$ & $\begin{array}{c}-0.201 \\
(0.092)^{* *}\end{array}$ & $\begin{array}{l}-0.190 \\
(0.209)\end{array}$ & $\begin{array}{c}0.187 \\
(0.165) \\
\end{array}$ & & & & & $\begin{array}{c}0.101 \\
(0.078) \\
\end{array}$ & $\begin{array}{c}0.089 \\
(0.087)\end{array}$ & $\begin{array}{c}0.198 \\
(0.180) \\
\end{array}$ & $\begin{array}{l}-0.215 \\
(0.223)\end{array}$ & & & & \\
\hline $\mathrm{R}^{2}$ within & 0.114 & 0.115 & 0.029 & 0.054 & 0.048 & 0.055 & 0.027 & 0.035 & 0.125 & 0.135 & 0.026 & 0.072 & 0.123 & 0.117 & 0.031 & 0.067 \\
\hline$R^{2}$ between & 0.006 & 0.013 & 0.004 & 0.000 & 0.008 & 0.030 & 0.002 & 0.003 & 0.004 & 0.014 & 0.008 & 0.001 & 0.011 & 0.025 & 0.007 & 0.002 \\
\hline $\mathrm{R}^{2}$ overall & 0.002 & 0.021 & 0.006 & 0.008 & 0.007 & 0.029 & 0.005 & 0.008 & 0.014 & 0.028 & 0.012 & 0.014 & 0.022 & 0.038 & 0.017 & 0.018 \\
\hline F & 640.3 & 643.7 & 93.6 & 231.5 & 29.3 & 33.8 & 12.2 & 18.5 & 234.9 & 257.4 & 33.0 & 109.7 & 21.4 & 20.3 & 4.1 & 10.1 \\
\hline$F\left(\right.$ for all $\left.u_{i}\right)$ & 21.9 & 18.4 & 9.8 & 12.4 & 18.1 & 14.1 & 10.7 & 10.2 & 23.1 & 19.3 & 11.0 & 11.1 & 21.7 & 19.1 & 6.9 & 8.6 \\
\hline OBS & 106,896 & 106,438 & 71,587 & 89,749 & 12,235 & 12,181 & 9269 & 10,935 & 34,208 & 34,166 & 26,673 & 29,749 & 3102 & 3098 & 2638 & 2887 \\
\hline GROUPS & 27,335 & 27,294 & 21,143 & 24,559 & 3519 & 3509 & 2858 & 3213 & 7849 & 7842 & 6747 & 7355 & 809 & 806 & 722 & 776 \\
\hline
\end{tabular}

$\mathrm{t}$-Student in parentheses; significance indicated as follows: ${ }^{* *} 0.01,{ }^{* *} 0.05,{ }^{*} 0.1$ 


\section{Concluding Remarks}

The financial strategies of a firm arise from a very complex process and neither the theories related to capital structure nor the existing empirical models appear to be completely effective in exhaustively explaining such strategies. Most findings of previous empirical studies on firms' capital structure are significantly affected or limited by the samples on which they are based. Nevertheless, in our opinion, the findings of the analysis presented here allow us to expand what we know about the capital structure of firms in less advanced areas, especially smaller firms.

First, the findings reported above mostly confirm the direction of the relationships between firm-level determinants, on the one hand, and small firms' capital structure, on the other hand. However, through our investigation of a large sample of SMEs in the Italian Mezzogiorno, which is a perfectly integrated, but slowly growing macro-area in the South of the country, we have verified that there are several significant differences in the regional leverage model when it is compared to the model for Italian firms as a whole. Some of these differences confirm what we already knew, for example, that firms in less advanced areas have a lower propensity to use financial leverage and a significantly higher propensity to use bank leverage. This phenomenon can be explained by the fact that it is more difficult for those firms to resort to alternative sources of finance, at the same time as there are pressures on their capacity to draw on internal finance, which means that the latter is insufficient to finance current activities, let alone the growth of the firm. Thus, the dependence on bank funding further increases. The other findings are equally notable, but it seems to us that these are affected by the dramatic events that occurred in the final years of the previous decade. They tell us that consequent to both the shock to credit supply and the dramatic fall in production, there was a reorganization of debt, specifically showing a prevalence of the replacement of short-term debt with long-term debt.

Nevertheless, from the estimation of the fixed-effects panel, other findings seem to emerge, suggesting more important structural differences in the binding of the regional leverage models. This is where our study contributes to the empirical literature on small firms' capital structure in underdeveloped areas. Although the impact of the size and age variables on the leverage of Southern firms was not significantly different from that in the rest of Italy, the elasticity of both the profit rate and the riskiness variables were unexpectedly lower than for the firms located in other regions. We may try explaining these surprising findings in the following way. First, one should note that the standard leverage model is unable to entirely capture these differences because of the importance attached to fixed effects; this is coherent with the information asymmetry approach; and the estimated fixed effects (as mainly measured by the constant) suggest that the weight of the omitted variables is great. On the basis of such evidence, we suggest that there is a need to deepen the analysis in the direction of testing how much of the fixed effects can be explained by the efficiency of local institutions or regional financial and legal systems, as well as the extent to which unexplored individual effects seem to arise. To some extent, this is the direction taken by the literature in recent years (see Section 2.2 above). In this regard, the findings presented here may be understood as a partial confirmation of the arguments put forward by, in particular, La Rocca et al. $(2010,2011)$.

Secondly, the empirical evidence presented here emphasizes the distinctive features of the financial structure of Southern Italian SMEs. Our findings show that Southern Italian firms are unexpectedly over-capitalized, as the share of equity is considerably higher; and, correspondingly, Southern SMEs exhibit an excess of productive capacity revealed by a higher ratio of fixed to total assets. Thus, cross-regional differences in the impact of both the profit ratio and firms' asset structure variables on leverage in the regional models may confirm the hypothesis that over-capitalization or over-capacity cannot be entirely explained by the presence of a larger informal environment or by very likely accounting constraints imposed by the incentives promoting fixed investments in less developed areas. We suspect that these conditions could actually warrant equilibrium for firms in less developed areas, which are, however, perfectly integrated in domestic and foreign financial markets. The difficulties in accessing alternative financial sources make firms more dependent on internal finance and on bank 
resources, and (small) firms have to choose the capital structure that eases the relationship with the banking system. In spite of the fact that appreciable gains in terms of financial management arise from such a relationship, this condition results in inefficiency for firms. It is not unlikely that there is a significant deadweight loss and that firms are hindered from exploiting growth opportunities and the propensity to innovate.

Finally, the analysis enabled us to distinguish between the model for small firms and that for medium-sized firms, reaffirming the increasingly widespread notion that the determinants explaining the capital structure choices of larger firms are equally effective in explaining the financial choices of smaller firms; naturally, the doubt that the standard empirical model is able only partially to explain firms' financial strategies remains.

The specificity of capital structure choices facing small firms in underdeveloped areas, such as Southern Italy, as shown in this study, also has policy implications. First, over-capitalization shows that industrial policy should target small firms' excessive productive capacity and find ways to reduce it while helping small firms to grow in size-an important challenge for macro-areas, such as the Mezzogiorno. Secondly, given Southern Italian small firms' persistently high levels of indebtedness, the current, ongoing transformations of the Italian banking system should be steered towards guaranteeing mechanisms to reduce the costs of excessive leverage on firms' capital structure.

Author Contributions: O.B. was mainly involved to review the economic analysis on this field examining the determinants of the capital structure choice at the firm level as much as at the country level. D.S. was principally working with the methodological approach and he was engaged with the econometric model. The empirical analysis as much as the concluding section are the result of the joint working of both the authors.

Funding: This research received no external funding.

Conflicts of Interest: The authors declare no conflicts of interest.

\section{References}

Adedeji, Abimbola. 1998. Does the Pecking Order Hypothesis Explain the Dividend Payout Ratios of Firms in the UK? Journal of Business Finance \& Accounting 25: 1127-55.

Beattie, Vivien, Alan Goodacre, and Sarah Jane Thomson. 2006. Corporate Financing Decisions: UK Survey Evidence. Journal of Business Finance E Accounting 33: 1402-34.

Beck, Thorsten, Asli Demirgüç-Kunt, and Ross Levine. 2003. Law, Endowment and Finance. Journal of Financial Economics 70: 137-81. [CrossRef]

Beck, Thorsten, Asli Demirgüç-Kunt, and Ross Levine. 2005. Law and Firms' Access to Finance. American Law and Economics Review 7: 211-52.

Beck, Thorsten, Asli Demirgüç-Kunt, and Vojislav Maksimovic. 2008. Financing Patterns Around the World: Are Small Firms Different? Journal of Financial Economics 89: 467-87. [CrossRef]

Berger, Allen N., and Gregory F. Udell. 1998. The Economics of Small Business Finance: the Role of Private Equity and Debt Markets in the Financial Growth Cycle. Journal of Banking and Finance 22: 613-73. [CrossRef]

Booth, Laurence, Varouj Aivazan, Asli Demirgüç-Kunt, and Vojislav Maksimovic. 2001. Capital Structures in Developing Countries. The Journal of Finance 55: 87-130. [CrossRef]

Capitalia, ed. 2002. Indagine sulle imprese manifatturiere, VIII rapport. Milano: Il Sole-24 Ore.

Carter, Richard, and Howard Van Auken. 2006. Small Firm Bankruptcy. Journal of Small Business Management 44: 493-512. [CrossRef]

Cassar, Gavin, and Scott Holmes. 2003. Capital Structure and Financing of SMEs: Australian Evidence. Accounting and Finance 43: 123-47. [CrossRef]

Chittenden, Francis, Graham Hall, and Patrick Hutchinson. 1996. Small Firm Growth, Access to Capital Markets and Financial Structure: Review of Issue and an Empirical Investigation. Small Business Economics 8: 59-67. [CrossRef]

Dang, Chongyu, Zhichuan F. Li, and Chen Yang. 2018. Measuring Firm Size in Empirical Corporate Finance. Journal of Banking \& Finance January 86: 159-76.

Daskalakis, Maria, and Nikolaos Psillaki. 2008. Do Country or Firm Factors Explain Capital Structure? Evidence from SMEs in France and Greece. Applied Financial Economics 18: 87-97. [CrossRef] 
De Angelo, Harry, and Ronald Masulis. 1980. Optimal Capital Structure under Corporate and Personal Taxation. Journal of Financial Economics 8: 3-29. [CrossRef]

De Jong, Abe, Kabir Rezaul, and Thuy Nguyen. 2008. Capital Structure Around the World: the Roles of Firm-and Country-specific Determinants. Journal of Banking E Finance 32: 1954-69.

Demirgüç-Kunt, Asli, and Vojislav Maksimovic. 1999. Institutions, Financial Markets, and Firm Debt Maturity. Journal of financial economics 54: 295-336. [CrossRef]

Di Pietro, Filippo, Maria E. Bontempi, Mariaa-Jose Palacin, and Reyes Samaniego-Medina. 2016. Capital Structure across Italian Regions: The Roles of Financial and Economic Determinants. Unpublished Working Paper. Available online: https://papers.ssrn.com/sol3/papers.cfm?abstract_id=2988997 (accessed on 3 January 2019).

Donati, Cristiana. 2016. Firm Growth and Liquidity Constraints: Evidence from the Manufacturing and Service Sectors in Italy. Applied Economics 48: 1881-92. [CrossRef]

Fama, Eugene F., and Kenneth R. French. 2002. Testing Trade-off and Pecking Order Predictions about dividends and Debt. The Review of Financial Studies 15: 1-33. [CrossRef]

Fan, Joseph P., Sheridan Titman, and Garry Twite. 2012. An International Comparison of Capital Structure and Debt Maturity Choices. Journal of Financial and Quantitative Analysis 47: 23-56. [CrossRef]

Frank, Murray Z., and Vidhan K. Goyal. 2003. Testing the Pecking Order Theory of Capital Structure. Journal of Financial Economics 67: 217-48. [CrossRef]

Guiso, Luigi, Paola Sapienza, and Luigi Zingales. 2004. Does Local Financial Development Matter? Quarterly Journal of Economics 119: 929-69. [CrossRef]

Hall, Graham C., Patrick J. Hutchinson, and Nicos Michaelas. 2004. Determinants of the Capital Structure of European SMEs. Journal of Business Finance and Accounting 31: 711-28. [CrossRef]

Harris, Milton, and Artur Raviv. 1990. The Theory of Capital Structure. Journal of Finance 46: 297-355. [CrossRef]

Jensen, Michael C., and William H. Meckling. 1976. Theory of the Firm: Agency Costs and Ownership Structure. Journal of Financial Economics 3: 305-60. [CrossRef]

Jordan, Judith, Julian Lowe, and Peter Taylor. 1998. Strategy and Financial Policy in UK Small Firms. Journal of Business Finance \& Accounting 25: 1-27.

Klagge, Britta, Ron Martin, and Peter Sunley. 2017. The Spatial Structure of the Financial System and the Funding of Regional Business: A Comparison of Britain and Germany. In Handbook on the Geographies of Money and Finance. Edited by Martin Ron and Jane Pollard. Cheltenham: Edward Elgar Publishing, pp. 125-55.

Kraus, Alan, and Robert H. Litzenberger. 1973. A State-Preference Model of Optimal Financial Leverage. Journal of Finance 28: 911-22. [CrossRef]

La Porta, Rafael, Florencio Lopez-de-Silanes, Andrei Shleifer, and Robert W. Visny. 1997. Legal Determinant of External Finance. The Journal of Finance 53: 1131-50. [CrossRef]

La Porta, Rafael, Florencio Lopez-de-Silanes, Andrei Shleifer, and Robert W. 1998. Law and Finance. Journal of Political Economy 106: 1113-55. [CrossRef]

La Rocca, Maurizio, Tiziana La Rocca, and Alfio Cariola. 2010. The Influence of Local Institutional Differences on the Capital Structure of SMEs: Evidence from Italy. International Small Business Journal 28: 234-57. [CrossRef]

La Rocca, Maurizio, Tiziana La Rocca, and Alfio Cariola. 2011. Capital Structure Decisions During a Firm's Life Cycle. Small Business Economics 37: 107-30. [CrossRef]

Lawless, Martina, Brian O'Connell, and Conor O’Toole. 2015. Financial Structure and Diversification of European Firms. Applied Economics 47: 2379-98. [CrossRef]

Levine, Ross. 1997. Financial Development and Economic Growth: Views and Agenda. Journal of Economic Literature 35: 688-726.

Levine, Ross. 2004. Finance and Growth: Theory, Evidences and Mechanism. NBER Working Paper n.10766. Cambridge, MA, USA: National Bureau of Economic Research.

MacKay, Peter, and Gordon M. Philips. 2005. How Does Industry Affect Firm Financial Structure? Review of Financial Studies 18: 1433-66. [CrossRef]

Mateev, Miroslav, Panikkos Poutziouris, and Konstantin Ivanov. 2013. On the Determinants of SME Capital Structure in Central and Eastern Europe: A Dynamic Panel Analysis. Research in International Business and Finance 27: 28-51. [CrossRef] 
Matias, Fernanda, and Zelia Serrasqueiro. 2017. Are There Reliable Determinant Factors of Capital Structure Decisions? Empirical Study of SMEs in Different Regions of Portugal. Research in International Business and Finance 40: 19-33. [CrossRef]

Mediocredito, Centrale, ed. 1997. Indagine sulle imprese manifatturiere, VI rapport. Milano: Il Sole-24 Ore.

Mediocredito, Centrale, ed. 2000. Indagine sulle imprese manifatturiere, VII rapport. Milano: Il Sole-24 Ore.

Michaelas, Nicos, Francis Chittenden, and Panikkos Poutziouris. 1999. Financial Policy and Capital Structure Choice in UK SMEs: Empirical Evidence from Company Panel Data. Small Business Economics 12: 113-30. [CrossRef]

Miller, Merton H. 1977. Debt and Taxes. The Journal of Finance 32: 261-75.

Moritz, Alexandra, Joern H. Block, and Andreas Heinz. 2016. Financing Patterns of European SMEs-An Empirical Taxonomy. Venture Capital 18: 115-48. [CrossRef]

Myers, Stewart C. 1977. Determinants of Corporate Borrowing. Journal of Financial Economics 5: 147-75. [CrossRef] Myers, Stewart C. 1984. The Capital Structure Puzzle. The Journal of Finance 39: 574-92. [CrossRef]

Myers, Stewart C., and Nicholas S. Majluf. 1984. Corporate Financing and Investment Decisions When Firms Have Information That Investors Do Not Have. Journal of Financial Economics 13: 187-221. [CrossRef]

Noulas, Anastasios, and Georgios Genimakis. 2011. The Determinants of Capital Structure Choice: Evidence from Greek Listed Companies. Applied Financial Economics 21: 379-87. [CrossRef]

Palacín-Sánchez, Mariaa-Jose, and Filippo Di Pietro. 2016. The Role of the Regional Financial Sector in the Capital Structure of Small and Medium-Sized Enterprises (SMEs). Regional Studies 50: 1232-47. [CrossRef]

Palacín-Sánchez, Mariaa-Jose, Luis M. Ramírez-Herrera, and Filippo Di Pietro. 2013. Capital Structure of SMEs in Spanish Regions. Small Business Economics 41: 503-19. [CrossRef]

Psillaki, Maria, and Nikolaos Daskalakis. 2009. Are the Determinants of Capital Structure Country or Firm Specific? Small Business Economics 33: 319-33. [CrossRef]

Rajan, Raghuram G., and Luigi Zingales. 1995. What Do We Know About Capital Structure? Some Evidence from International Data. The Journal of Finance 50: 1421-60. [CrossRef]

Ross, Stephen A. 1977. The Determination of Financial Structure: The Incentive-Signalling Approach. The Bell Journal of Economics 8: 23-40. [CrossRef]

Serrasqueiro, Zeila, and Ana Caetano. 2015. Trade-Off Theory Versus Pecking Order Theory: Capital Structure Decisions in a Peripheral Region of Portugal. Journal of Business Economics and Management 16: 445-66. [CrossRef]

Wald, John K. 1999. How Firm Characteristics Affect Capital Structure: An International Comparison. Journal of Financial Research 22: 161-87. [CrossRef] 